\title{
PERILAKU DAN KARATERISTIK PESERTA DIDIK BERDASARKAN TUJUAN PEMBELAJARAN
}

\author{
Hani Hanifah ${ }^{1}$, Susi Susanti ${ }^{2}$, Aris Setiawan Adji $^{3}$ \\ Universitas muhammadiyah tangerang \\ hanihanifahhanifah07@gmail.com,Susisusanti16041@gmail.com
}

\begin{abstract}
This research provides readers with knowledge about the problem and and characteristics of the data discussed in the article. Characteristics and behavior refer to one's character and lifestyle and values that develop regularly so that conduct becomes better and more easily noticed by the student's character is also arguably a specific feature each student has as an individual ora group for consideration and the learning organizing process.
\end{abstract}

Keywords: Characteristics, Behavior, Learning

\begin{abstract}
Abstrak : Penelitian ini bertujuan memberi pengetahuan kepada para pembaca tentang perilaku dan karakteristik Data-data yang dikaji dalam artikel ini merupakan konseptual berdasarkan penelusuran pustaka yang telah dilakukan.karakteristik dan perilaku mengacu kepada karakter dan gaya hidup seseorang serta nilai nilai yang berkembang secara teratur.sehingga tingkah laku menjadi lebih baik dan mudah di perhatikan.karakter siswa juga bisa dibilang ciri khusus yang dimiliki oleh masing-masing siswa baik sebagai individu atau kelompok sebagai pertimbangan dalam proses perorganisasian pembelajaran.
\end{abstract}

Kata Kunci: Karakteristik, Perilaku, Pembelajaran

\section{PENDAHULUAN}

Dalam proses belajar mengajar antara guru dan peserta didik diperlukan sekali yang namanya pendekatan baik secara fisik maupun mental terlebih lagi guru sebagai seseorang yang mempunyai ilmu yang akan membagi ilmunya tersebut kepada peserta didik harus paham betul bagaimana perilaku serta karakteristik dari peserta didik yang akan dididik oleh guru tersebut. Banyak cara yang dapat dilakukan agar seorang guru sebagai tenaga pengajar yang berintegritas, bersinergi serta layaknya panutan dalam melakukan pengajaran terhadap peserta didik, langkah demi langkah, step by step dapat dipelajari agar seorang guru bisa memahami perilaku dan karakteristik peserta didiknya agar bisa menjadikan peserta didiknya mampu memahami ilmu - ilmu yang akan diberikan oleh gurunya tersebut.Setiap siswa dapat dipastikan memiliki perilaku

Manazhim : Jurnal Manajemen dan Ilmu Pendidikan

Volume 2, Nomor 1, Februari 2020; 105-117

https://ejournal.stitpn.ac.id/index.php/manazhim 
dan karakteristik yang sangat heterogen. Sebagian siswa sudah banyak tahu, sebagian lagi belum tahu sama sekali tentang materi yang diajarkan di kelas. Bila pengajar mengikuti kelompok siswa yang pertama, kelompok yang kedua merasa ketinggalan kereta, yaitu tidak dapat menangkap pelajaran yang diberikan. Sebaliknya, bila pengajar mengikuti kelompok yang kedua, yaitu mulai dari bawah, kelompok pertama akan merasa tidak belajar apa-apa dan bosan. ${ }^{1}$ Bagi setiap pengajar, mengetahui perilaku karakteristik awal siswa diperlukan dalam menyusun tujuan instruksional. Menurut Deterline (1965), teknologi instruksional merupakan aplikasi teknologi perilaku untuk menghasilkan perilaku khusus secara sistematik dalam rangka mencapai tujuan instruksional. ${ }^{2}$ Keadaan awal siswa yang heterogen dengan latar belakang serta kemampuan yang berbeda-beda akan jadi penghambat bagi proses pencapaian tujuan instruksional bila sejak awal pengajar tidak mengidentifikasi perilaku dan karakteristik siswa yang akan diajar sering sekali guru menentukan titik materi pembelajarannya berdasarkan halaman pertama yang terdapat dalam buku teks pelajaran. Padahal tidak selamanya pengetahuan siswa itu nol. Buku pelajaran tak dapat dijadikan bahan acuan menebak pengetahuan siswa,begitu juga dengan pandangan kasar mata seorang guru. Oleh karena itu,langkah yang perlu diambil adalah mengidentifikasi kemampuan dan karakteristik awal siswa. ${ }^{3}$

Peserta didik merupakan suatu organisme yang sedang tumbuh dan berkembang. Setiap dari peserta didik memiliki potensi masing-masing seperti bakat, minat, kebutuhan dan lain-lain. Oleh karena itu para peserta didik butuh dan perlu dikembangkan memalui pendidikan dan pengajaran, sehingga dapat tumbuh dan berkembang. Dalam era modern ini di bidang pendidikan, perbedaan karakteristik peserta didik perlu dipertimbangkan dan diperhatikan dalam kegiatan belajar mengajar. Maka dari itu, setiap pelaksanaan kegiatan belajar mengajar di sekolah harus sesuai dengan karakteristik, gaya belajar, dan kecerdasan masing masing peserta didik. Hal ini sejalan dengan pendapat Yeti dan Mumuh (2014: 72) yang menyatakan bahwa peserta didik dalam kegiatan pendidikan merupakan objek utama yang

${ }^{1}$ Atwi Suparman, Desain Instruksional Modern; Panduan Para Pengajar dan Inovator Pendidikan, (Jakarta: Erlangga, 2012), h. 178.

${ }^{2}$ Yusufhadi Miarso..dkk (pen), Defenisi Teknologi Pendidikan, (Jakarta: Rajawali, 1986) h. 47

${ }^{3}$ Rahmat Rifai Lubis, Identifikasi Perilaku dan Karakteristik. Awal Peserta Didik, Jurnal Hikmah, Vol.15, No.1 Januari- Juni 2018, hlm.28 
kepadanya ialah segala yang berhubungan dengan aktivitas pendidikan dirujukkan. Melihat penjelasan diatas, karakteristik, gaya belajar, kecerdasan peserta didik merupakan hal yang perlu diketahui oleh pelaksana pendidikan terutama pendidik yang secara langsung mendidik peserta didik tersebut. Bagi sesama peserta didik juga perlu diketahui agar dapat bertoleransi dengan sesama peserta didik yang memiliki perbedaan karakteristik. Guru dapat memberikan contoh sikap penerimaan dan toleransi sehingga peserta didik merasa nyaman di sekolah sekaligus untuk menanamkan nilai-nilai dan bahkan menikmati perbedaan diantara mereka tanpa adanya rasa curiga (Law Nolte \& Harris, 2016: 137). Dengan demikian karakteristik, gaya belajar, dan kecerdasan peserta didik perlu diketahui dan dipahami oleh para pelaksana pendidik agar dapat merancang rencana pelaksaanan pendidik dengan optimal. Dengan demikian juga jika masing masing karakterisitik peserta didik dipahami maka masing masing peserta didik akan merasa diperhatikan dan akan melaksanakan pembelajaran dengan menyenangkan tanpa tekanan.

\section{METODE}

Metode kualitatif adalah metode riset yang sifatnya memberikan penjelasan dengan menggunakan analisis. Pada pelaksanaannya, metode ini bersifat subjektif dimana proses penelitian lebih diperlihatkan dan cenderung lebih fokus pada landasan teori. Metode yang digunakan dalam pembuatan jurnal ini ialah metode kualitatif dimana penulis menggunakan analisis dan lebih banyak menggunakan teori yang ada dikaitkan dengan keaadaan yang nyata.

\section{HASIL DAN PEMBAHASAN}

\section{A. Pengertian Karakteristik Menurut Piuas Partanto, Dahlan (1994)}

Karakteristik berasal dari kata karakter dengan arti tabiat/watak, pembawaan atau kebiasaan yang dimiliki oleh individu yang relatif tetap. Menurut Moh. Uzer Usman (1989) Karakteristik adalah mengacu kepada karakter dan gaya hidup seseorang serta nilai-nilai yang berkembang secara teratur sehingga tingkah laku menjadi lebih konsisten dan mudah di perhatikan. Menurut Sudirman (1990) Karakteristik siswa 
adalah keseluruhan pola kelakuan dan kemampuan yang ada pada siswa sebagai hasil dari pembawaan dari lingkungan sosialnya sehingga menentukan pola aktivitas dalam meraih cita-citanya. Menurut Hamzah. B. Uno (2007) Karakteristik siswa adalah aspek-aspek atau kualitas perseorangan siswa yang terdiri dari minat, sikap, motivasi belajar, gaya belajar kemampuan berfikir, dan kemampuan awal yang dimiliki. Siswa atau anak didik adalah setiap orang yang menerima pengaruh dari seseorang atau sekelompok orang yang menjalankan pendidikan. Anak didik adalah unsur penting dalam kegiatan interaksi edukatif karena sebagai pokok persoalan dalam semua aktifitas pembelajaran (Saiful Bahri Djamarah, 2000) B. Pentingnya Identifikasi Karakteristik Peserta Didik dalam Pembelajaran. Berdasarkan landasan yuridis dan teoritik, perlu dilakukan identifikasi karakteristik peserta didik. Pertama Peraturan pemerintah No. 19 tahun 2005 tentang standar nasional pendidikan bahwa pengembangan pembelajaran dilakukan dengan memperhatikan; tuntutan, bakat, minat, kebutuhan, dan kepentingan siswa. Kedua secara teoretik siswa berbeda dalam banyak hal yang meliputi perbedaan fitrah individual disamping perbedaan latar belakang keluarga, sosial, budaya, ekonomi, dan lingkungan. Salah satu ciri kegiatan belajar mengajar adalah terjadinya interaksi antara guru dan siswa. Masing-masing memiliki tugas yang saling mendukung. Siswa bertugas untuk belajar dan guru bertugas mendampingi siswa dalam belajar. Dalam kegiatan belajar, siswa diharapkan mencapai tujuan pembelajaran tertentu yang meliputi tujuan umum dan tujuan khusus. Sesuai orientasi baru pendidikan, siswa menjadi pusat terjadinya proses belajar mengajar (student center), maka standar keberhasilan proses belajar mengajar itu bergantung kepada tingkat pencapaian pengetahuan, keterampilan dan afeksi oleh siswa. Oleh karenanya guru sebagai pendesain pembelajaran sudah seharusnya mempertimbangkan karakteristik siswa baik sebagai individu maupun kelompok. Setiap satuan kelas memiliki karakteristik yang berbeda. Heterogenitas kelas menjadi salah satu keniscayaan yang harus dihadapai guru. Sebagai pendesain pembelajaran guru harus menjadikan karakteristik siswa sebagai salah satu tolak ukur bagi perencaan dan pengelolaan proses belajar mengajar. Proses belajar mengajar di sekolah dasar memiliki corak yang berbeda dengan proses belajar mengajar di sekolah menengah. Karakteristik siswa itu sesuai dengan tahap-tahap perkembangan siswa. Misalnya, keberhasilan dalam bidang akademik di sekolah dasar menjadi hal utama 
sebagai salah satu pencapaian keberhasilan seorang siswa, oleh karenanya penghargaan terhadap mereka yang memiliki kemampuan akademis tinggi akan sangat dirasakan. Sebaliknya bagi mereka yang duduk di bangku sekolah menengah, mulai memiliki pergesaran paradigma terhadap makna keberhasilan belajar. Perkembangan siswa akan berjalan lurus dengan kompleksitas masalah yang dihadapi oleh guru. Kenyataan lain yang juga harus dihadapi guru adalah meski mereka menghadapi kelompok kelas dengan umur yang relatif sama tetapi guru tidak bisa memperlakukan sama terhadap perbedaan karakteristik siswa. Setiap satuan kelas itu berbeda dalam hal motivasi belajar, kemampuan belajar, taraf pengetahuan, latar belakang, dan sosial ekonomi. Hal ini mengharuskan guru memperlakukan satuan kelas itu dengan pendekatan yang berbeda. Memahami heterogenitas siswa berarti menerima apa adanya mereka dan merencakan pembelajaran sesuai dengan keadaannya. Program pembelajaran di sekolah dasar akan berlangsung efektif jika sesuai dengan karakteristik siswa yang belajar. Smaldino dkk, mengemukakan empat faktor penting yang harus diperhatikan dalam menganalisis karakter siswa:

(1) Karakteristik umum;

(2) kompetensi atau kemampuan awal;

(3) gaya belajar;

(4) motivasi.

Berkaitan dengan motivasi sangat diperlukan untuk memberi dorongan bagaimana siswa melakukan akativitas belajar agar menjadi kompeten dalam bidang yang dipelajari. Karekteristik Umum Karakteristik umum pada dasarnya menggambarkan tentang kondisi siswa seperti usia, kelas, pekerjaan, dan gender. Karakteristik siswa merujuk kepada ciri khusus yang dimiliki oleh siswa, dimana ciri tersebut dapat mempengaruhi tingkat keberhasilan pencapaian tujuan belajar. Karakteristik siswa merupakan ciri khusus yang dimiliki oleh masing-masing siswa baik sebagai individu atau kelompok sebagai pertimbangan dalam proses pengorganisasian pembelajaran. Winkel mengaitkan karakteristik siswa dengan penyebutan keadaan awal, dimana keadaan awal itu bukan hanya meliputi kenyataan pada masing-masing siswa melainkan pula kenyataan pada masing-masing guru. Cruickshank mengemukakan 
beberapa karakteristik umum siswa yang perlu mendapatkan perhatian dalam mendesain proses atau aktivitas pembelajaran, yaitu:

(1) kondisi sosial ekonomi,

(2) faktor budaya,

(3) jenis kelamin,

(4) partumbuhan,

(5) gaya belajar dan

(6) kemampuan belajar.

Semua karakteristik yang bersifat umum perlu dipertimbangkan dalam menciptakan proses belajar yang dapat membantu individu mencapai kemampuan yang optimal. Analisis karakteristik awal siswa merupakan salah satu upaya yang dilakukan untuk memperoleh pemahaman tentang; tuntutan, bakat, minat, kebutuhan dan kepentingan siswa, berkaitan dengan suatu program pembelajaran tertentu. Tahapan ini dipandang begitu perlu mengingat banyak pertimbangan seperti; siswa, perkembangan sosial, budaya, ekonomi, ilmu pengetahuan dan teknologi, serta kepentingan program pendidikan/pembelajaran tertentu yang akan diikuti siswa.

Menurut Suparman ada dua pendekatan yang dapat dipilih. Pertama, siswa menyesuaikan dengan materi pelajaran dan kedua, sebaiknya materi pelajaran disesuaikan dengan siswa.

Pendekatan pertama, siswa menyesuaikan dengan materi pelajaran, dapat dilakukan sebagai berikut:

\section{Seleksi Penerimaan Siswa}

a. Pada saat pendaftaran, siswa diwajibkan memiliki latar belakang pendidikan yang relevan dengan program pendidikan yang akan diambilnya;

b. Setelah memenuhi syarat-syarat pendaftaran di atas, siswa mengikuti tes masuk dalam pengetahuan dan keterampilan yang sesuai dengan program pendidikan yang akan ditempuhnya. Proses seleksi ini sering dilakukan oleh lembaga-lembaga pendidikan formal seperti sekolah dalam menyeleksi calon 
siswa untuk memasuki sekolah-sekolah menengah negeri yang ingin memilih calon siswa yang baik.

2. Tes dan Pengelompokan Siswa

Setelah melalui seleksi seperti dijelaskan dalam butir 1, masih ada kemungkinan pengajar menghadapi masalah heterogennya siswa yang mengambil mata pelajaran tertentu. Karena itu, perlu dilakukan tes sebelum mengikuti pelajaran untuk mengelompokkan siswa yang boleh mengikuti mata pelajaran tersebut. Selanjutnya atas dasar hasil tes setiap kelompok tersebut mengikuti tingkat pelajaran tertentu. Tes dan pengelompokan ini biasa dilakukan oleh lembagalembaga pengelola kursus bahasa Inggris.

3. Lulus Mata Pelajaran Prasyarat

Alternatif lain untuk butir 2 di atas adalah mengharuskan siswa lulus mata pelajaran yang mempunyai prasyarat. Dalam suatu program pendidikan seperti di sekolah menengah pertama terdapat sebagian kecil mata pelajaran yang seperti itu.

Pendekatan kedua, materi pelajaran disesuaikan dengan siswa. Pendekatan ini hampir tidak memerlukan seleksi penerimaan siswa. Pada dasarnya, siapa saja boleh masuk dan mengikuti pelajaran tersebut.

Kedua pendekatan di atas bila dilakukan secara ekstrem, tidak ada yang sesuai untuk mengatasi masalah heterogennya siswa dalam sistem pendidikan biasa. Karena itu, marilah kita lihat pendekatan ketiga yang mengkombinasikan kedua pendekatan di atas. Pendekatan ketiga ini mempunyai ciri sebagai berikut:

a. Menyeleksi penerimaan siswa atas dasar latar belakang pendidikan atau ijazah. Seleksi ini biasanya lebih bersifat administratif.

2. Melaksanakan tes untuk mengetahui kemampuan dan karakteristik awal siswa. Tes ini tidak digunakan sebagai alat menyeleksi siswa, tetapi untuk dijadikan dasar penyusunan bahan pelajaran.

3. Menyusun bahan instruksional yang sesuai dengan kemampuan dan karakteristik awal siswa.

4. Menggunakan sistem instruksional yang memungkinkan siswa maju menurut kecepatan dan kemampuan masing-masing. 
5. Memberikan supervisi kepada siswa secara individual.

Dari uraian singkat tersebut diperoleh gambaran bahwa perilaku dan karakteristik awal siswa penting karena mempunyai implikasi terhadap penyusunan bahan belajar dan sistem instruksional.

\section{PERILAKU AWAL}

Dalam ilmu psikologi, perilaku adalah segenap manifestasi hayati individu dalam berinteraksi dengan lingkungan, mulai dari perilaku yang paling nampak sampai yang tidak tampak, dari yang dirasakan sampai yang tidak dirasakan. Dalam interaksinya, seseorang bisa menimbulkan perilaku yang bermacam-macam. Bila dikaitkan dengan belajar dan pendidikan, perilaku bergeser mengalami sebuah perubahan, misalnya, perilaku buruk menjadi baik, dari tidak terampil menjadi terampil, dari tidak tahu menjadi tahu, dan lain sebagainya. Dalam menentukan sebuah sistem instruksional, terdapat tiga macam sumber yang dapat memberikan informasi kepada pendesain instruksional dalam menentukan prilaku awal siswa, yaitu:

\section{Siswa atau calon siswa}

2. orang-orang yang mengetahui kemampuan siswa atau calon siswa dari dekat seperti pengajarnya terdahulu atau atasannya

3. pengelola program pendidikan yang biasa mengajarkan mata pelajaran tersebut.

Teknik yang dapat digunakan untuk mengidentifikasi perilaku awal siswa yaitu kuesioner, interview, observasi, dan tes. Subjek yang memberikan informasi diminta untuk mengidentifikasi seberapa jauh tingkat penguasaan siswa atau calon siswa dalam setiap perilaku khusus melalui skala penilaian.

Teknik yang dapat menghasilkan data yang lebih akurat adalah tes penampilan siswa dan observasi terhadap pelaksanaan pekerjaan siswa serta tes tertulis untuk mengetahui tingkat pengetahuan siswa. Tetapi bila tes semacam ini tidak dapat atau tidak tepat untuk dilaksanakan karena beberapa sebab, penggunaan skala penilaian cukup memadai. Skala penilaian tersebut diisi oleh orang-orang yang tahu secara dekat terhadap kemampuan siswa dan diisi oleh siswa sendiri sebagai self-report. Tidak semua aspek dari keadaan siswa pada awal proses belajar mengajar sama-sama 
penting; aspek mana yang penting sebagai titik tolak dalam interaksi guru-murid selama pelajaran berlangsung tergantung dari tujuan instruksional. Misalnya, dalam rangka pelajaran sejarah, tidak relevan ditinjau apakah siswa sudah mampu mengapung dalam air, karena pelajaran itu tidak bertujuan membekali siswa dengan kemampuan berenang. Yang relevan ialah meninjau, sampai berapa jauh siswa memiliki suatu kerangka historis, sehingga peristiwa yang terjadi pada tahun 1990 akan ditangkap sebagai peristiwa yang belum lama terjadi, dibanding dengan peristiwa yang terjadi pada tahun 1950. menyelidiki apakah siswa sudah mampu mengapungkan badannya dalam air (tingkah laku awal), baru menjadi relevan dalam pelajaran pendidikan jasmani yang bertujuan supaya siswa mampu berenang dengan gaya katak (tingkah laku final).

Inilah pentingnya bagi pengajar untuk mengetahui perilaku awal siswa, karena dari perilaku inilah tergantung bagaimana proses belajar mengajar sebaiknya diatur dan apakah tujuan instruksional khusus yang mula-mula ditetapkan harus mengalami perubahan. Hal ini lebih-lebih berlaku bila perilaku awal itu menyangkut suatu kemampuan yang diperlukan untuk mencapai tujuan instruksional. Ketika pengajar telah mengetahui perilaku awal siswa, perlu kiranya memperhatikan hasil tersebut bagi pengembangan tujuan instruksional. Perlu diperhatikan bahwa tugas selanjutnya bagi pengajar tidak hanya sekedar menyesuaikan perilaku awal siswa dengan desain instruksional saja, tetapi lebih dari itu, pengajar harus mempunyai cara dalam memodifikasi tingkah laku awal menjadi tingkah laku final yang ingin dituju. Seorang psikolog terkenal Fred. S. Keller, merancang suatu program modifikasi tingkah laku bagi suatu kursus non gelar dalam psikologi umum.telah mendapatkan hasil yang memuaskan sehingga prosedur-prosedurnya dipakai untuk kursus-kursus psikologi atau bidang akademi lain di universitas-universitas beberapa negara. Programnya tersebut menekankan kepada individualisasi dalam kecepatan belajar, penentuan tujuan pendidikan, evaluasi yang dilakukan terus menerus untuk menentukan tingkat kemajuan setiap siswa dalam mencapai tujuan instruksional.

\section{KARAKTERISTIK AWAL}

Di samping mengidentifikasi perilaku awal siswa, pengembang instruksional harus pula mengidentifikasi karakteristik siswa yang berhubungan dengan keperluan 
pengembangan instruksional. Minat siswa pada umumnya, misalnya pada olah raga dan musik, karena sebagian besar siswa adalah penggemar musik, dapat dijadikan bahan dalam memberikan contoh dalam rangka penjelasan materi pelajaran. Kemampuan siswa yang kurang dalam membaca bahasa Inggris merupakan masukan pula bagi pengembang instruksional untuk memilih bahan-bahan pelajaran yang tidak berbahasa Inggris atau menerjemahkannya terlebih dahulu ke dalam bahasa Indonesia. Demikian pula bila siswa senang dengan humor. Pendesain instruksional sebaiknya mempertimbangkan penggunaan lelucon dalam strategi instruksionalnya. Bila siswa sebagian besar tidak mempunyai video di rumah, pendesain instruksional tidak dapat membuat program video untuk dipelajari siswa di rumah. Informasi di atas perlu dicari oleh pengembang instruksional sehingga ia dapat mengembangkan sistem instruksional yang sesuai dengan karakteristik siswa/siswa. Teknik yang dapat digunakan dalam mengidentifikasi karakteristik awal siswa sama dengan teknik yang digunakan untuk mengidentifikasi perilaku awal, yaitu kuesioner, interview, observasi dan tes.7 Seperti halnya dalam mencari informasi perilaku awal siswa, informasi yang dikumpulkan pendesain instruksional terbatas pada karakteristik siswa yang ada manfaatnya dalam proses pengembangan instruksional. Tujuan mengetahui karakteristik siswa adalah untuk mengukur, apakah siswa akan mampu mencapai tujuan belajarnya atau tidak; sampai di mana minat siswa terhadap pelajaran yang akan dipelajari. Bila siswa mampu, hal-hal apa yang memperkuat; dan bila tidak mampu hal-hal apa yang menjadi penghambat. Hal-hal yang perlu diketahui dari siswa bukan hanya dilihat faktor-faktor akademisnya, tetapi juga dilihat faktor-faktor sosialnya, sebab kedua hal tersebut sangat mempengaruhi proses belajar siswa/siswa. Hal-hal yang perlu diketahui tersebut adalah:

\section{Faktor-faktor akademis}

- Berapa jumlah siswa dalam satu kelas

- Apa latar belakang pendidikan (sekolah yang pernah ditempuh)

- Bagaimana nilai rata-rata yang dicapai tiap sekolah/kursus/latihan yang pernah dialami - Apakah siswa mempunyai kebiasaan belajar sendiri

- Bagaimana kebiasaan belajar siswa 
- Apakah siswa sudah mengetahui sedikit tentang latar belakang pokok bahasan yang akan dipelajari

- Apakah tingkat intelegensi siswa tinggi, sedang atau rendah

- Apakah siswa mampu membaca cepat - Apa saja yang dikuasai oleh siswa (student achievement)

- Bagaimana motivasi belajar siswa

- Apakah yang menjadi harapan siswa setelah mempelajari pokok bahasan tersebut

- Bagaimana aspirasi kebudayaan dan vokasional siswa.

\section{Faktor-faktor sosial}

- Umur

- Kematangan

- Perhatian (minat)

- Apakah ada siswa teladan dalam satu kelas

- Apakah ada siswa yang cacat fisik

- Bagaimana hubungan antarsiswa

- Bagaimana latar belakang sosial-ekonomis.

\section{Kondisi belajar Menurut Dunn \& Dunn}

kondisi belajar dapat mempengaruhi konsentrasi, penerapan dan penerimaan informasi. Pengaruh kondisi lingkungan tempat belajar terhadap seseorang dapat mengakibatkan reaksi yang berbeda-beda. Kita sering menyaksikan bahwa anak-anak muda lebih suka belajar sambil mendengarkan musik dari radio atau tape recorder di sampingnya, dengan volume yang cukup besar. Sementara orang lain lebih suka belajar dengan ruangan yang tenang. Dunn \& Dunn membagi kondisi belajar menjadi empat golongan:

a. Lingkungan fisik (physical environment), seperti pengaruh suaru, cahaya, temperatur, dan pengaturan meja-kursi serta perabotan setempat. 
b. Lingkungan emosional (emotional environment), seperti, motivasi individu, ketepatan tugas, dan tanggung jawab.

c. Lingkungan sosiologis (sociological environment), seperti kebiasaan belajar/bekerja sendiri atau bersama, tanggapan terhadap orang/pejabat yang sedang berkuasa, dan sebagainya.

d. Kondisi fisiologis siswa sendiri (student's owns physiological make up), seperti ketajaman dan kelemahan indera, kebutuhan gizi, tidak atau terlalu banyak mobilitas, penghargaan terhadap waktu sehari-hari, irama kehidupan, dan bagaimana sikapnya terhadap efesiensi tugas-tugasnya.

Untuk mengetahui kebiasaan dan kesenangan belajar tiap siswa, pengajar menyusun kuesioner, atau langsung mencari informasi dari tiap siswa tentang kondisi mana yang lebih disukai. Hal ini akan menolong pengajar dalam membantu cara belajar siswa.

\section{Teknik belajar Ada siswa/siswa yang belajar lebih efektif dan ada yang tidak.}

Ada yang lebih mudah mengerti dengan pendekatan visual, ada yang mudah menangkap verbal, dan ada yang lebih cocok bila ada kegiatan praktek, latihan, aktivitas fisik, atau simulasi. Identifikasi teknik belajar ini berkaitan dengan usaha meningkatkan perhatian siswa, dan ini disebut cognitive style mapping. Teknik menyediakan suatu kerangka dalam menggambar dan mencari sebab-sebab, mengapa individu-individu mempunyai teknik belajar yang berbeda-beda. Ada tiga hal yang perlu diuji sehubungan dengan tingkah laku siswa sebagaimana:

a. Sampai seberapa jauh seorang siswa dapat menangkap lambang-lambang teoritis baik berupa kata-kata ataupun angka-angka, ketajaman panca indera, dan penangkapan terhadap hal-hal yang subjektif seperti hal-hal yang berhubungan dengan kebudayaan.

b. Bagaimana pengaruh siswa terhadap hal-hal yang diperoleh dari lambang-lambang teoritis di atas. 
c. Bagaimana tabiat siswa dalam memberi alasan, bagaimana pendekatan pendekatan yang dilakukan oleh siswa terhadap suatu masalah dan proses penyimpulannya.

d. Bagaimana kekuatan daya ingat siswa.

Untuk mendapatkan data dari keempat hal tersebut mungkin bisa melalui tes diagnosis atau kuesioner. Hasil dari padanya merupakan merupakan indikasi karakteristik, latar belakang akademis dan sosial siswa yang akan berguna dalam pelaksanaan, baik pengajaran individu maupun kelompok.

\section{KESIMPULAN}

Dari uraian diatas dapat disimpulkan bahwa setiap perserta didik memiliki karakteristik yang berbeda-beda,dari gaya belajar nya pun juga berbeda.oleh karena itu setiap pelaksaan pendidikan harus bisa memahami semua sifat karakteristik.guru pun juga bisa membuat metode pembelajaran yang lebih efektif.

\section{DAFTAR PUSTAKA}

Miarso Yusufhadi. 1986. Defenisi Teknologi Pendidikan. Jakarta:Rajawali. Suparman, Atwi. 2012. Desain Instruksional Modern. Jakarta:Erlangga.

Rita Dunn \& Kenneth Dunn, Educator's Self Teaching Guide to Individualizing Instructional Programs (New York: Parker Publishing Co., 1975), h. 74-93,

Lubis, Rahmat Rifai, (Januari - Juni 2018). "Identifikasi Perilaku dan Karakteristik. Awal Peserta Didik”. Jurnal Hikmah. Vol 15 No.1.

Mudhoffir, Teknologi Instruksional (Bandung: Remaja Rosdakarya, 1999), h. 101-102 NIZHAMIYAH Vol. VIII, No.2, Juli - Desember 2018 ISSN : 2086 - 420565 